\title{
Test-day model of daily milk yield prediction across stages of lactation in Egyptian buffaloes
}

\section{Summary}

Test-day records of 10515 daily milk yield (TDY) observations of Egyptian buffaloes were collected from four farms in Ismailia region, which exist east of Cairo. Two data sets were considered for analysis of variance according to lactation length. The first data set is TDY of the short lactation (5-10 months: $\left.\mathrm{LP}_{\mathrm{S}}\right)$. The $2^{\text {nd }}$ data set is the TDY of the long lactation $\left(\mathrm{LP}_{\mathrm{L}}>305\right.$ days). Daily milk yield prediction equations were investigated using multiple lactations, separate lactations, and three groups of age at first calving. Polynomial regression functions were fitted to study the effect of stage of lactation on variation in test-day milk yield observations (TDY). Results of the present study showed that the effect of herd (farm, season and year of calving) on variation of TDY were significant and accounted for $35.22 \%$ of the total variance for the data set of $\mathrm{LP}_{\mathrm{L}}$. Variations in TDY due to the effect of either order of lactation or age at first calving groups were significant and accounted for $8.25 \%$ and $13.50 \%$, respectively of the total variance. The overall least-square means of TDY were 5.5 and 7.8 $\mathrm{Kg}$ for $\mathrm{LP}_{\mathrm{S}}$ and $\mathrm{LP}_{\mathrm{L}}$, respectively. The highest frequencies of similar TDY observations appeared in the early months across stage of lactation. The peak of the measured TDY obtained among the $4^{\text {th }}$ and the $6^{\text {th }}$ month of lactation of the pooled parity data set. Prediction equation of TDY across days of lactation (Days in Milk:DIM) using pooled parities was as the following:

$$
\boldsymbol{Y}=3.4103+.0466 \boldsymbol{X}-.0004 \boldsymbol{X}^{2}+.00001 \boldsymbol{X}^{3}-1.03 \mathrm{E}-8 \boldsymbol{X}^{4}
$$

Prediction equation of TDY across months of lactation (Months in Milk:MIM) using pooled parity data set was as the following:

$$
\boldsymbol{Y}=1.9634+2.7927 \boldsymbol{X}-.8931 \boldsymbol{X}^{2}+.1602 \boldsymbol{X}^{3}-.0138 \boldsymbol{X}^{4}
$$

Prediction equations for TDY per parity and for each age at first calving group were computed.

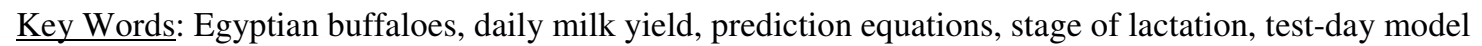

\section{Zusammenfassung}

Titel der Arbeit: Testtagsmodell zur Vorhersage der täglichen Milchleistung nach unterschiedlichen Laktationsabschnitten bei ägyptischen Büffelkühen

Erfasst wurden 10515 tägliche Milchleistungsdaten (TDY) von 429 ägyptischen Büffelkühen mit 5 Laktationen in vier Betrieben der Ismailia Region, östlich von Kairo gelegen. Für die Varianzanalyse wurden zwei Datensätze, die durch eine unterschiedliche Laktationslänge gekennzeichnet waren, betrachtet. Der erste Datensatz beinhaltet TDY bei einem kürzeren Laktationsabschnitt von 5-10 Monaten (LP $\left.{ }_{S}\right)$ und der zweite den längeren Abschnitt von $>305$ Tagen $\left(\mathrm{LP}_{\mathrm{L}}\right)$. Für die Voraussageschätzung der TDY wurden die Gesamtlaktationen sowie die Einzellaktationen bei drei Gruppen in Abhängigkeit vom Erstkalbealter betrachtet. Die multiple Regressionsfunktion wurde an die Prüfung des Effektes unterschiedlicher Laktationsstadien auf die Vorhersage der TDY angepasst. Die Ergebnisse der Studie zeigten, dass der Herdeneffekt (Betrieb, Saison und Kalbejahr) auf die Variation der TDY signifikant war und 35,22 \% der Gesamtvarianz des Datensatzes LP $_{\mathrm{L}}$ betrug. Die Variation der TDY in Abhängigkeit von Laktationen oder Erstkalbealter war signifikant und betrug 8,25\% bzw. 13,50 \% der Gesamtvarianz. Der Gesamtmittelwert der TDY betrug 5,5 bzw. 7,8 Milch-Kg. Eine hohe Übereinstimmung zu den erfassten TDY Daten scheint in den frühen Laktationsstadien zu bestehen. So lag die größte Übereinstimmung des Datensatzes zwischen dem 4. und 6. Laktationsmonat. Für die Vorhersage der TDY mittels Laktationstagen wurde folgende Gleichung genutzt:

$$
\boldsymbol{Y}=3.4103+.0466 \boldsymbol{X}-.0004 \boldsymbol{X}^{2}+.00001 \boldsymbol{X}^{3}-1.03 \mathrm{E}-8 \boldsymbol{X}^{4}
$$

Für die Vorhersage der TDY mittels Laktationsmonat wurde folgende Gleichung genutzt:

$$
\boldsymbol{Y}=1.9634+2.7927 \boldsymbol{X}-.8931 \boldsymbol{X}^{2}+.1602 \boldsymbol{X}^{3}-.0138 \boldsymbol{X}^{4}
$$

Die Vorhersagegleichung für TDY je Kalbung und die unterschiedlichen Erstkalbealtersgruppen wurde berechnet. 
Schlüsselwörter: Ägyptische Büffelkühe, täglicher Milchertrag, Vorhersagegleichung, Laktationsstadium, Testtagsmodell

\section{Introduction}

Genetic and phenotypic evaluation models in dairy cattle use test-day records instead of 305 days lactation records are of great interest in the field of genetic improvement and breeding programs for production traits (SCHAEFFER and DEKKERS, 1994; KETTUNEN et al., 1998). Prediction of daily milk yield is very essential as a basis for decisions to cull or to retain a dairy animal at an earlier stage of lactation (HANAA et al., 1998). The models for production traits are known as test-day model and can account for the effect of test date, number, order and intervals between test-day records and provide information about persistency (SCHAEFFER and DEKKERS, 1994; REENTS and DOPP, 1996). A common approach to investigate genetic associations between traits varying over time is to consider every trait at each time period as a separate trait and then to estimate the genetic correlations between these traits (VEERKAMP and THOMPSON, 1999). Therefore the present study will try to explain variations in TDY of Egyptian buffaloes using test-day model.

Buffaloes are the first native dairy animal in Egypt. Intensive buffalo farms in Egypt are very little. The small farmer is raising the most Egyptian Buffaloes individuals. Therefore applying results of the recent research for improving milk production of Egyptian Buffalo are very difficult. Determine and analysis the most important factors influencing milk yield of Egyptian buffalo are very important to characterize strategy of genetic improvement. Several factors are known to influence the shape of lactation curve of Egyptian buffalo (RAGAB et al., 1973). Variation in milk yield either total or daily yield due to variation in age at calving were very significant (KHALIL, 1993; RASHAD, 1989; MOURAD, 1984; REDDY and TANEJA, 1984). KAWTHER and KHATTAB (1992) found that estimates of linear and quadratic regression coefficients of $305 \mathrm{MY}$ on age at first calving and age at calving in the fourth parity were not significant, while the corresponding estimates of linear regression was only significant in the $2^{\text {nd }}$ and the $3^{\text {rd }}$ parity. METRY et al. (1994) found significant negative correlation among persistency and season of calving. Also they found a significant linear and quadratic regression of TDY persistency on age at calving. Maximum daily yield in the $1^{\text {st }}$ lactation appeared at the 48 month of age (KAWTHAR and KHATTAB, 1992). Overall mean of daily milk yield of Murrah buffaloes were $5.13 \pm 0.312,5.27 \pm 0.36$, and $5.14 \pm 0.29$ in the $1^{\text {st }}, 2^{\text {nd }}$ and $3^{\text {rd }}$ parity, respectively (SINGH and YADAV, 1987).

This study was carried out to investigate the effect of stage of lactation (days and months in milk) on variations in the observed values of test-day milk yield. Another objective of the present study was to suggest appropriate polynomial regression function for prediction of TDY using data sets of pooled parities, separate parities, and four ages at first calving groups.

\section{Materials and Methods}

Data collection and structure: Data of test-day milk yield of 429 Egyptian buffaloes distributed over a period of 6 years (from January 1995 until December 2000) were obtained from four different farms located in Ismailia region. All available records of identified or non-identified animals were collected. Total number for test-day yields 
(TDY) observations were 10515 records. The present study was concerned with the first 5 successive parities. The current study involved two data sets according to length of lactation period. The first data set involved animals with 5-10 months of lactation (short lactation: $\mathrm{LP}_{\mathrm{S}}$ ). While the second data set involved animals with lactation longer than 10 months (long lactation: $\mathrm{LP}_{\mathrm{L}}$ ). Three age at first calving groups were classified as shown in Table 1. Prediction equations of daily milk yield using days in milk or months in milk were computed. Prediction of daily milk yield was applied in the categories of i) multiple lactation, ii) the first five parities separately, and iii) age at first calving groups. The intervals between the calving date and the TDY observation date were computed by subtraction. The present data included TDY observations for most days of milking across 390 days of lactation. In sequences, for each computed 30-days across stages of lactation was presented as one month of lactation. The present data set involved computed 13 months of lactation and their average of TDY (Fig. 1).

Table 1

Age at first calving groups (AFC)

\begin{tabular}{cccccccc}
\hline AFC (months) & $\begin{array}{c}\text { Average } \\
\text { age }\end{array}$ & $\begin{array}{c}\text { Individual } \\
\text { Numbers }\end{array}$ & $\begin{array}{c}\text { Obs. } \\
\text { No. }\end{array}$ & \multicolumn{2}{c}{ TDY \pm SE } & \multicolumn{2}{c}{ Min-Max } \\
Kg
\end{tabular}

Obs.No.: Observation Numbers

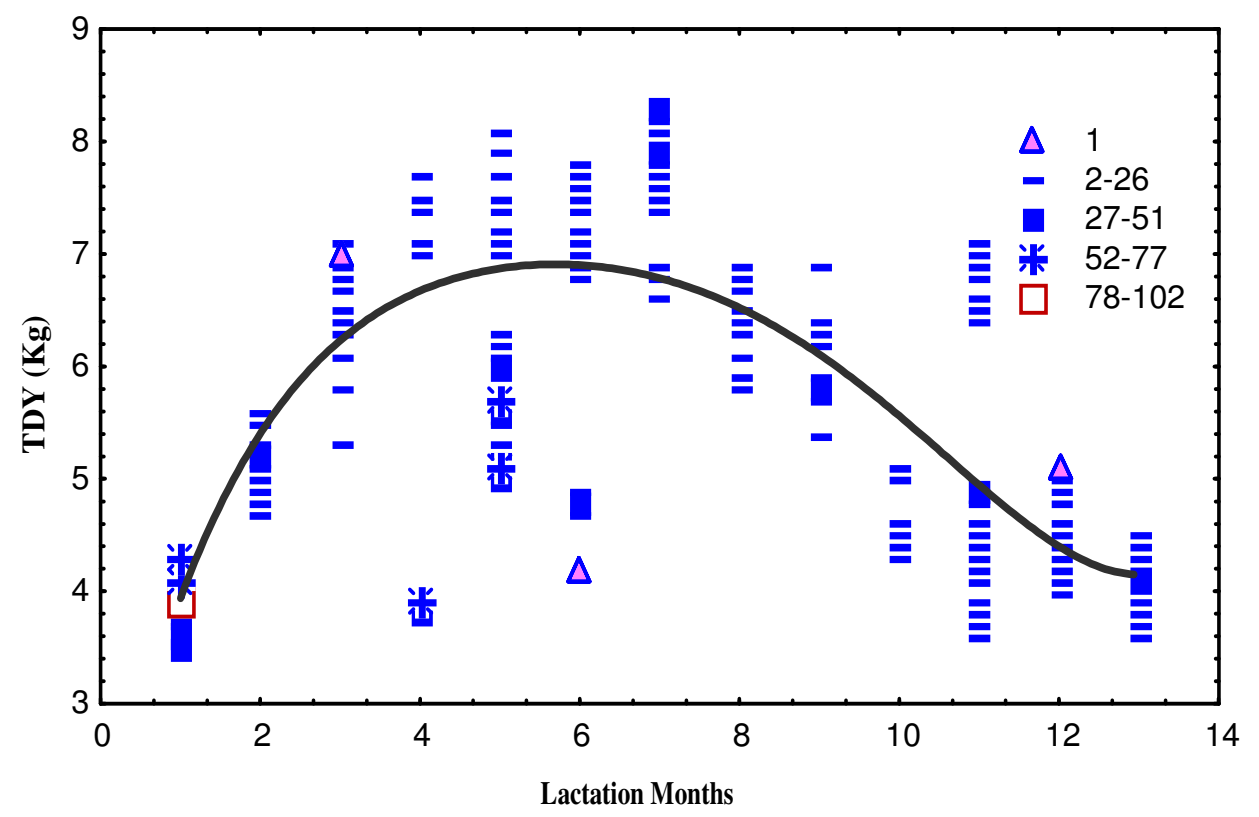

Fig. 1: Frequencies of similar test-day milk yield (TDY) observations across months of lactation of the pooled parities

Multi-trait animal models (multi-traits derivative free restricted maximum likelihood procedure MT-DF-REML, (BOLDMAN, 1997) was used to explore variations in testday yield due to non-genetic effects. Sire half-sib sisters covariances were estimated applying Proc IML and Proc Plot and TRANSREG (SAS-6.12 1998) which was used for fitting solutions of polynomial regressions functions. Prediction equations for TDY 
across days (DIM: 390 days) and months (MIM: 13 months) of lactation were created using the pooled parities, separate parities and age at first calving groups.

The general mathematical models used were:

Where:

$$
\begin{aligned}
& Y_{i j k l m}=u+H_{i}+A_{j}+S_{k}+P_{l}+\beta_{S t g}{ }^{N}+e_{i j k l m \ldots \ldots . .(\text { model } 1)} \\
& Y_{i j k l m}=u+H_{i}+A_{j}+S_{k}+A g e_{l}+\beta_{S t g}{ }^{N}+e_{i j k l m \ldots . . .(\text { model } 2)}
\end{aligned}
$$

$Y_{i j k l m}$ : is the test-day milk yield

$\mu$ : Population mean, $H_{i}$ : fixed effect of $i^{\text {th }}$ herd (that involved effect of farm, season and year of calving), $A_{j}$ : is the effect of $\mathrm{j}^{\text {th }}$ animal, $S_{k}$ is the effect of $\mathrm{k}^{\text {th }}$ sire assumed to be randomly distributed around zero with variance $A \sigma^{2} s$, (A is the numerator relationship matrix between sires), $P_{l}$ : fixed effect of $1^{\text {th }}$ order of lactation $(1=1$ to 5 parity): model 1, or $\mathrm{Age}_{l}$ : is the effect of $1^{\text {th }}$ group of age at first calving : model 2. $\beta_{S t g}{ }^{N}$ : is the partial linear and nonlinear regression $(N:$ is the power of regression function) of test-day yield on stage of lactation, $e_{i j k l m}:$ is the residual randomly distributed around 0 with variance $I \sigma^{2}$, where $I$ is the identity matrix.

Separate analyses of variance were also applied either for separate parities or for age at first calving groups.

\section{Results and Discussion}

Results in Table 2 show the influence of stage of lactation on variation of TDY (fitted in the mathematical model as a covariant) was significant for $\mathrm{LP}_{\mathrm{L}}$ in data set of the pooled parities. On the other hand changes in the level of TDY across stages of lactation were significant in the data set of the $1^{\text {st }}$ parity (Table 2 and Figure 2). Influence of stage of lactation as a covariant on variation in TDY was higher using $\mathrm{LP}_{\mathrm{L}}$ than using $\mathrm{LP}_{\mathrm{S}}$ in both data sets. This result indicates the clear influence of stage of lactation on variation in TDY its progressive nature with increasing length of lactation period.

Table 2

Sum of squares ratio for test-day milk yield in the studied data sets.

\begin{tabular}{cccccc}
\hline & \multicolumn{2}{c}{ MS \% - all parities } & \multicolumn{2}{c}{ MS \% - $1^{\text {st }}$ parity } \\
SOV & $\mathrm{LP}_{\mathrm{S}}$ & $\mathrm{LP}_{\mathrm{L}}$ & $\mathrm{SOV}$ & $\mathrm{LP}_{\mathrm{S}}$ & $\mathrm{LP}_{\mathrm{L}}$ \\
\hline Random & $23.03^{\mathrm{s}}$ & $27.18^{\mathrm{s}}$ & Random & $21.30^{\mathrm{s}}$ & $21.11^{\mathrm{s}}$ \\
Herd & $26.91^{\mathrm{s}}$ & $25.25^{\mathrm{s}}$ & Herd & $35.22^{\mathrm{s}}$ & $33.15^{\mathrm{s}}$ \\
Parity & $13.30^{\mathrm{s}}$ & 10.08 & Age & 8.25 & $13.50^{\mathrm{s}}$ \\
Covariant & $14.11^{\mathrm{s}}$ & $18.05^{\mathrm{s}}$ & Covariant & $16.50^{\mathrm{s}}$ & $20.19^{\mathrm{s}}$ \\
Residual & 22.65 & 19.44 & Residual & 18.73 & 12.05 \\
\hline
\end{tabular}

MS\%: Mean-squares ratio, $\mathrm{S}$ : significant, $\mathrm{LP}_{\mathrm{S}}$ : short lactation, $\mathrm{LP}_{\mathrm{L}}$ : long lactation

Variations in TDY due to effects of age at first calving groups and order of lactation were significant (Table 2) and accounted $8.25 \%$ and $13.30 \%$, respectively. The lowest contribution for the effect of age at first calving groups on variation in TDY was occurred for data set of $\mathrm{LP}_{\mathrm{S}}$ in the $1^{\text {st }}$ parity.

Variations in TDY due to herd effect (farm-year-season of calving) was significant for all data sets. Herd effect was accounted for the highest proportion of variance compared to the other effects (Table 2). These results were in agreement with results reported by Metry et al. (1994) and Salem (1983). The highest contribution for herd effect was computed with analysis the data set of $\mathrm{LP}_{\mathrm{S}}$ of the $1^{\text {st }}$ parity. 


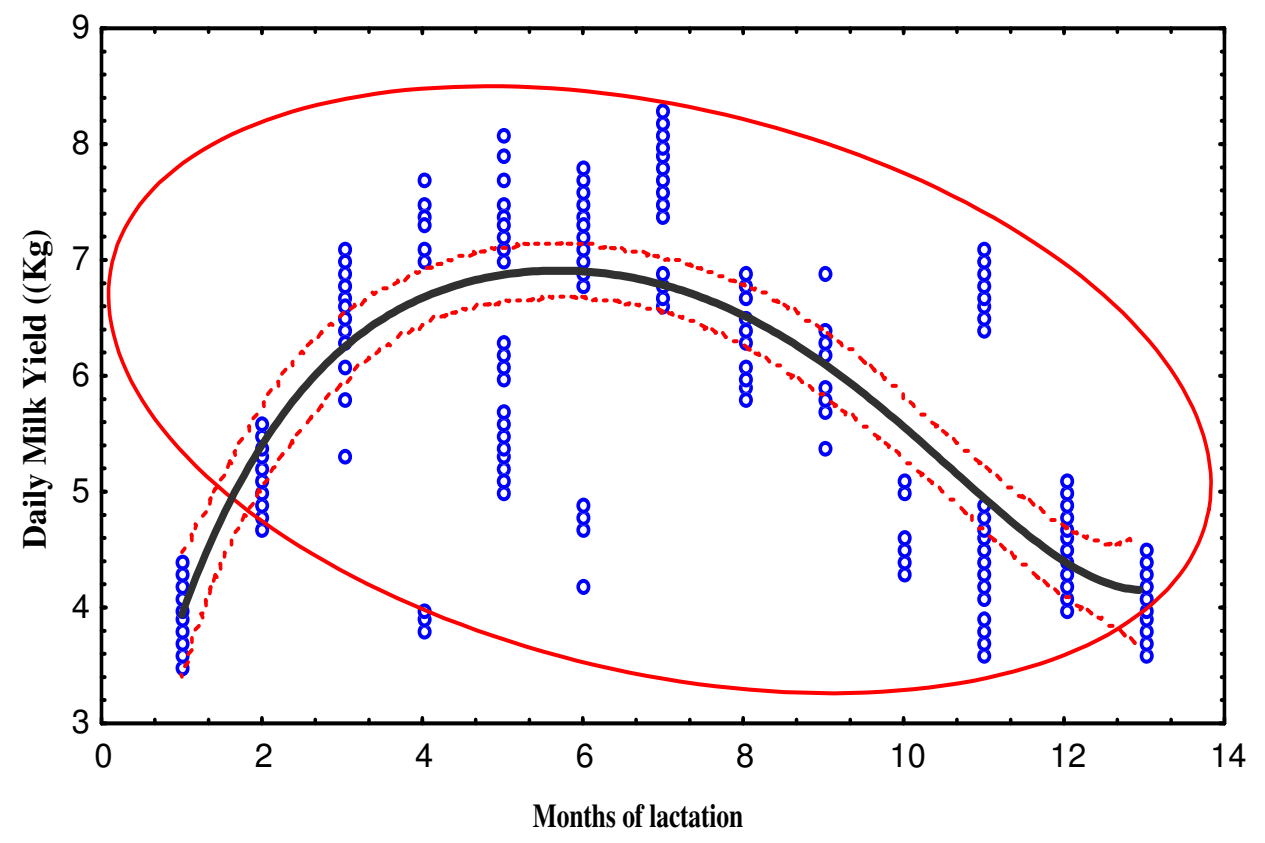

Fig. 2: Confidence band for the polynomial test-day milk yield across months of lactation of the pooled parities

Least-square means of TDY of different season of calving are presented in Table 3. The highest TDY appeared in winter and autumn calving and followed by spring and summer calving. Variation in TDY between winter and autumn vs. spring and summer may be attributed to changes of climate conditions among different seasons of calving also due to changes in feeding regimes. These results are in agreement with MOURAD et al. (1990) and MADALENA et al. (1979). Significant effects of calving season on variation in TDY were reported in several studies (ASHMAWY, 1991; KOTBY et al., 1988; KHATTAB et al., 1985).

Table 3

Least square means (LSM) and coefficient of variability (CV) for milk yield in different season of calving

\begin{tabular}{|c|c|c|c|c|c|c|c|c|}
\hline \multirow{2}{*}{ Season } & \multicolumn{4}{|c|}{ Short lactation } & \multicolumn{4}{|c|}{ Long lactation } \\
\hline & $\begin{array}{l}\text { Obs. } \\
\text { No. }\end{array}$ & $\begin{array}{c}\text { TDY } \\
\mathrm{Kg}\end{array}$ & $\begin{array}{c}\text { LP } \\
\text { days }\end{array}$ & $\begin{array}{l}\mathrm{CV} \\
\%\end{array}$ & $\begin{array}{l}\text { Obs. } \\
\text { No. }\end{array}$ & $\begin{array}{c}\text { TDY } \\
\text { Kg }\end{array}$ & $\begin{array}{c}\text { LP } \\
\text { days }\end{array}$ & $\begin{array}{c}\mathrm{CV} \\
\%\end{array}$ \\
\hline Winter & 984 & 6.49 & 298 & 44.1 & 2342 & 8.47 & 330 & 33.7 \\
\hline Spring & 642 & 5.77 & 219 & 28.7 & 1351 & 4.58 & 370 & 29.4 \\
\hline Summer & 551 & 5.41 & 198 & 32.4 & 1194 & 5.04 & 390 & 27.9 \\
\hline Autumn & 942 & 7.70 & 254 & 45.9 & 2509 & 8.49 & 340 & 31.4 \\
\hline
\end{tabular}

Obs. No. Observation numbers, TDY: Test-day yield, LP: Lactation Length

Overall means of test-day yield per parity are presented in Table 4. The least-square means for TDY of $\mathrm{LP}_{\mathrm{S}}$ and $\mathrm{LP}_{\mathrm{L}}$ ranged from 3.6 to $7.2 \mathrm{Kg}$ /day and from 5.8 to 9.5 $\mathrm{Kg}$ /day, respectively. These results were in agreement with RAGAB et al. (1973) and SALEM (1983). The highest numbers of TDY observations were present in the $2^{\text {nd }}$ parity of the $\mathrm{LP}_{\mathrm{L}}$ data set. Level of TDY increased with advancing order of lactation in all analyzed data sets till the $4^{\text {th }}$ parity. The rate of increasing TDY from the $1^{\text {st }}$ to the $2^{\text {nd }}$ parity was higher than among the other parities for both data sets. On the other hand, the rate of reduction in the level of TDY from the $4^{\text {th }}$ parity to the $5^{\text {th }}$ parity was higher for $\mathrm{LP}_{\mathrm{L}}$ than for $\mathrm{LP}_{\mathrm{S}}$ data set (Table 4). 
Table 4

Least-squares means (LSM) and coefficient of variability (CV) for daily milk yield (Kg) in the first five parities

\begin{tabular}{cccccccc}
\hline & \multicolumn{3}{c}{ Short Lactation } & & \multicolumn{3}{c}{ Long Lactation } \\
\cline { 2 - 3 } \cline { 6 - 7 } Parity & Obs.No. & Mean & CV\% & & Obs.No. & Mean & CV\% \\
\hline 1 & 785 & 3.6 & 28.4 & & 1582 & 5.8 & 24.7 \\
2 & 513 & 5.2 & 32.9 & & 1833 & 7.4 & 24.9 \\
3 & 728 & 6.9 & 31.4 & & 1457 & 8.7 & 22.7 \\
4 & 436 & 7.2 & 26.7 & & 1367 & 9.5 & 25.1 \\
5 & 657 & 6.2 & 29.4 & & 1157 & 7.3 & 29.3 \\
Overall & 3119 & 5.5 & 28.7 & & 7396 & 7.8 & 32.7 \\
\hline
\end{tabular}

Figure 1 shows frequencies of the similar TDY observations on the same point across months of lactation of the pooled parities. Five categories of the similar TDY observations according to the rate of their frequencies were created and presented in Figure 1. Categories of repeated TDY observations were 1, 2-26, 27-51, 52-77, and 78-102 times. In general the highest TDY values were presented through the $4^{\text {th }}$ and $6^{\text {th }}$ months of lactation of the pooled parities. Also the most categories frequencies of the similar TDY observations were presented across months of middle lactation. These results may indicate great amount of variation among TDY values will be presented across days and months of middle lactation. The highest distributions of similar TDY observations were obtained for the $2^{\text {nd }}$ category and for the $3^{\text {rd }}$ category. The highest category of the similar TDY observation was the $5^{\text {th }}$ category and it was obtained once time in the first month of lactation. Also TDY observations which repeated once time were little and presented in the early months of lactation.

Lactational polynomial curve of TDY across months of lactation was explored in Figure 2. Also level of confidence band at 95\% for TDY observations was presented in Figure 2. The results of confidence interval indicate the differences around mean across stage of lactation were similar except in the later months of lactation.

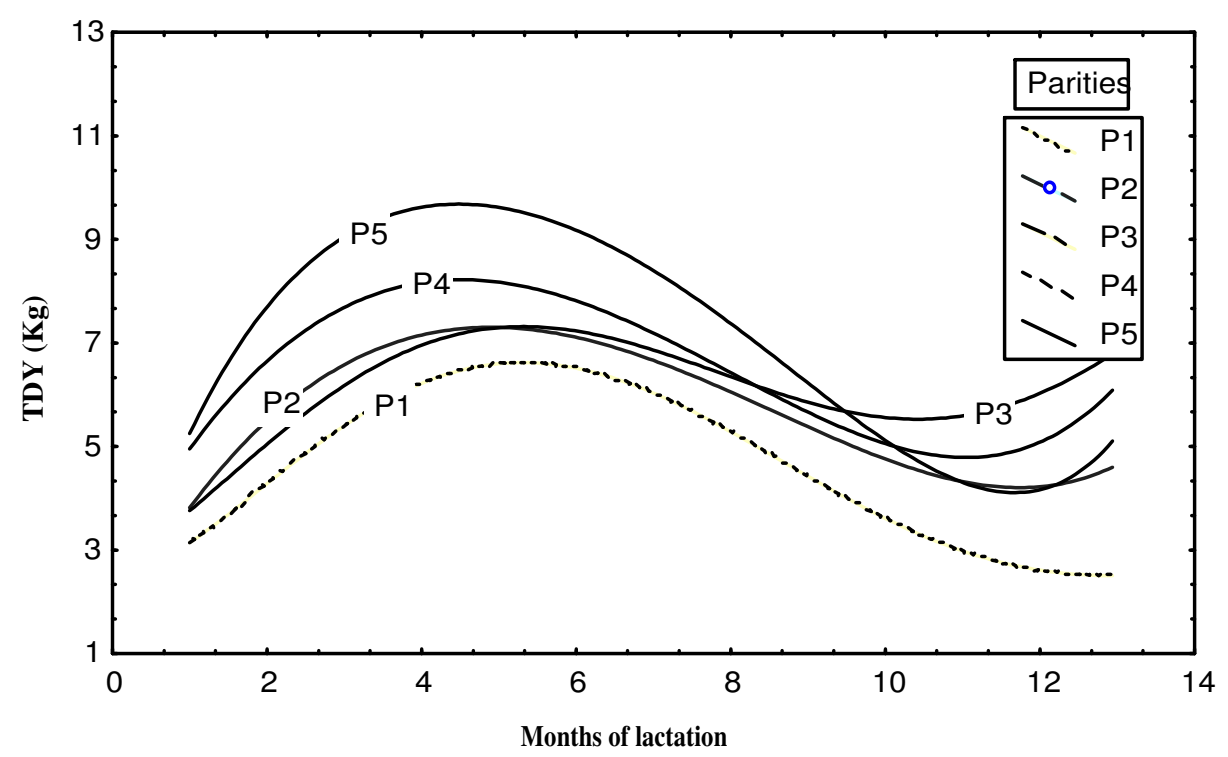

Fig. 3: Polynomial curve of test-day milk yield in the first five parities across months of lactation

Figure 3 shows estimates of TDY across months of lactation in the first five parities. The highest estimates for TDY were obtained across the $4^{\text {th }}$ to the $6^{\text {th }}$ month of lactation for all parities. Variations in TDY among months of lactation are much more 
for the $1^{\text {st }}$ parity $v s$. both the $4^{\text {th }}$ and the $5^{\text {th }}$ parities. On the other hand the corresponding variation in TDY among the $2^{\text {nd }} v s$. the $3^{\text {rd }}$ parities were very little. Lactational curve of the $3^{\text {rd }}$ parity was crossed in 4 points with the lactational curve of the other parities. The starting and finishing points of TDY on lactational curve were similar for the $2^{\text {nd }}$ parity with the $3^{\text {rd }}$ parity and for the $2^{\text {nd }}$ parity with the $5^{\text {th }}$ parity, respectively. The highest TDY observation obtained for the $5^{\text {th }}$ parity in the $4^{\text {th }}$ month of lactation. On the other hand, estimates of TDY in later months of the $5^{\text {th }}$ parity were less than the corresponding estimates of the $3^{\text {rd }}$ and the $4^{\text {th }}$ parity.

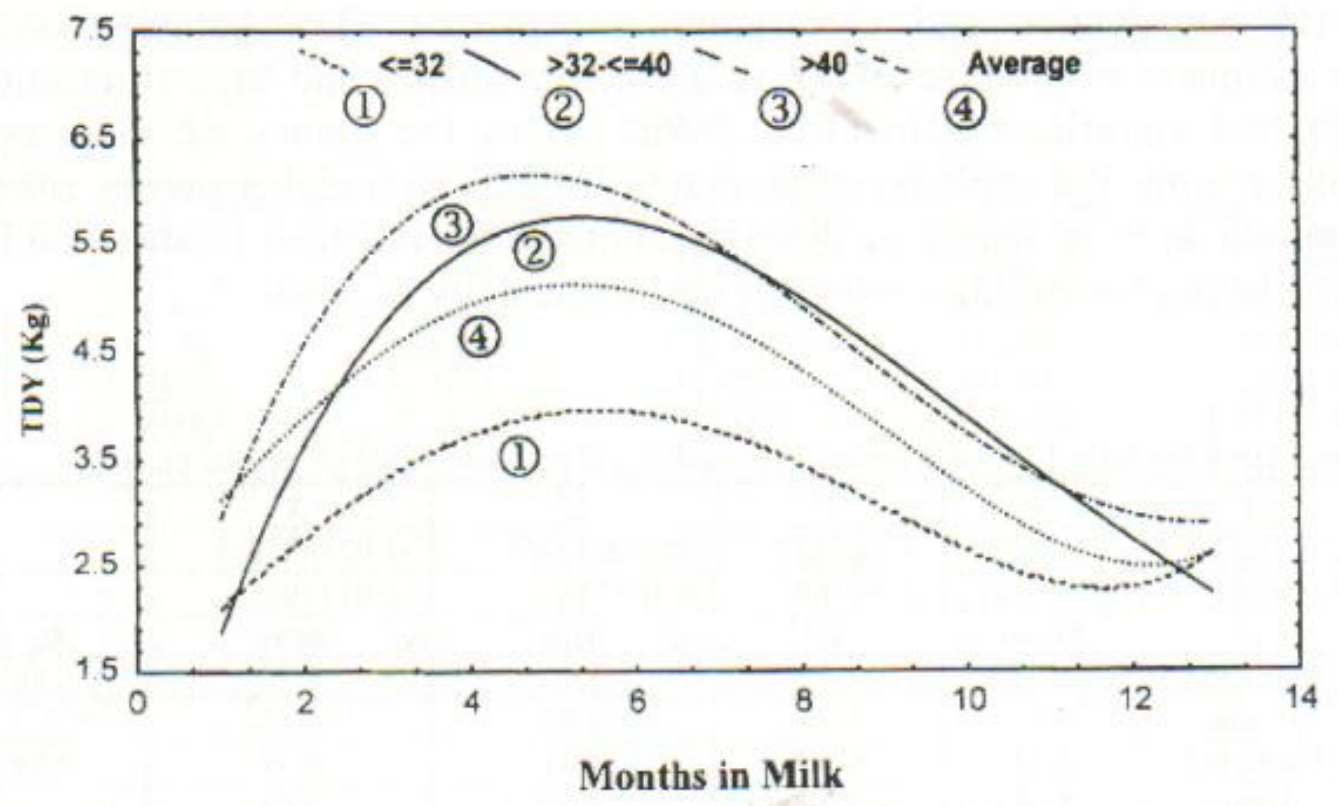

Fig. 4: Polynomial prediction curve for test-day milk yield across stage of lactation for age at first calving groups

Variations in TDY across months of lactation among four age at first calving groups were explained and plotted in Figure 4. The highest TDY occurred for the highest age at first calving group ( $>40$ months) across $4^{\text {th }}$ to $6^{\text {th }}$ months of lactation. Lactational curve of TDY for the age group of $>40$ months was declined rapidly to the end of lactation than the others. While the endpoint of TDY on the lactational curve of age group $>40$ months was higher than the other age groups. Differences in TDY measures among overall mean and age group of $>40$ months were very little across the $7^{\text {th }}$ to the $11^{\text {th }}$ months of lactation. Also across the $7^{\text {th }}$ to the $11^{\text {th }}$ months of lactation occurred a great deference in observed values of TDY of age group $\leq 32$ months than the age group $>40$ months. The lowest level in TDY obtained for age group of $>32-\leq 40$ as at the $1^{\text {st }}$ and $13^{\text {th }}$ months of lactation. Starting levels of TDY lactation curve were approximately similar for age groups of $>32-\leq 40$ with $\leq 32$ months and for overall mean with age group of $>40$ months. On the other hand starting level of TDY lactational curve $>40$ and overall mean were higher than the others. Differences in TDY among age at first calving groups at the end points of their lactation curves were very smaller.

\section{Test-day milk yield prediction}

Daily (DIM) and monthly (MIM) test-day yield (TDY) prediction equations are presented in Table 5-a. Polynomial functions of the $4^{\text {th }}$ degree was the optimal model for estimating predicted TDY values across months and days of lactation using pooled 
parities data set. All partial regression coefficients were significant at $p<0.01$. Across 390 days of lactation, it could estimate the predicted TDY values by substituting $\mathrm{X}=1$ to 390 days in milk in DIM equation. Across 13 months of lactation, it could estimate predicted TDY/month by substituting $\mathrm{X}=1$ to 13 months in milk in MIM equation. Standard deviations, minimum and maximum actual and predicted TDY observations across days and months of lactation of pooled parities are presented in Table 5-a. Range of predicted TDY values was higher than the corresponding estimates for actual DIM-TDY, while the opposite results were obtained for MIM-TDY. Accuracy estimates $\left(R_{a p}\right)$ of TDY predicted values were the correlation coefficients between actual TDY observation and corresponding predicted TDY values (Table 5-a). Accuracy estimates of predicted TDY values across months and days of lactation were very high and significant. Therefore prediction of the values of TDY could be suggested for using and applying in the practical fields with high accuracy either using days or months in milk. Applying these equations in the practical fields could help the farmer for planing his culling strategy of unsuitable dairy animals.

Table 5-a

Prediction equations for daily milk yield across days (DIM) and months (MIM) of pooled parities

\begin{tabular}{|c|c|c|c|c|c|c|}
\hline & $\bar{A}$ & $\bar{X}$ & $X^{2}$ & $X^{3}$ & $X^{4}$ & \\
\hline DIM & 3.410263 & 0.046596 & -0.000427 & 0.000002969 & $-1.029895 \mathrm{E}-8$ & \\
\hline MIM & 1.963401 & 2.792702 & -0.893085 & 0.160228 & -0.013793 & \\
\hline \multicolumn{3}{|r|}{ Mean } & $S D$ & Min & $\operatorname{Max}$ & $R_{p a} \pm S E$ \\
\hline \multirow{2}{*}{ DIM } & Predicted & 5.71 & 1.12 & 3.70 & 8.10 & $0.86^{\mathrm{s}} \pm .19$ \\
\hline & Actual & 5.62 & 0.96 & 3.68 & 6.83 & \\
\hline \multirow{2}{*}{ MIM } & Predicted & 5.58 & 0.99 & 4.01 & 6.79 & $0.89^{\mathrm{s}} \pm .11$ \\
\hline & Actual & 5.61 & 1.22 & 3.97 & 7.61 & \\
\hline
\end{tabular}

S: significant at $\mathrm{P}<0.01$

Lactational daily and monthly predicted TDY equations of separate parities are presented in Table 5-b. Polynomial functions of the $4^{\text {th }}$ degree represent the optimal model for estimating predicted TDY values across days (DIM) and months (MIM) of lactation for the first successive five parities, separately. All partial regression coefficient of DIM and MIM were significant. In DIM equations, estimates of intercept increased gradually with advancing order of lactation. The same trend was observed with estimates of MIM equations except that for the $5^{\text {th }}$ parity although they were generally lower than those estimates for DIM equations. Accuracy estimates of the TDY predicted values were ranged from 0.79 to 0.94 and from 0.75 to 0.92 for DIM and MIM, respectively. In addition, accuracy estimates of DIM-TDY were higher than the corresponding estimates MIM-TDY across all parities except for the $3^{\text {rd }}$ and the $4^{\text {th }}$ parity. In the first three parities, the highest positive partial regression coefficients were obtained for the linear degree of the polynomial function of DIM and MIM. Changing estimates of partial regression coefficients of the $3^{\text {rd }}$ degree among parities were greater for DIM than for MIM. In addition, rate of changing partial regression coefficient of $X^{2}$ of both models was low compared with other positive polynomial degrees.

Daily (DIM) and monthly (MIM) test-day yield prediction equations per age at first calving groups are presented in Table 5-c. Polynomial functions of the $4^{\text {th }}$ degree were the optimal regression model for predicted TDY across days and months of lactation for age at first calving groups. 
Table 5-b

Prediction equations for daily milk yield across days (DIM) and months (MIM) of lactation per parity

\begin{tabular}{|c|c|c|c|c|c|c|c|c|c|c|}
\hline DIM & \multicolumn{2}{|c|}{$1^{\text {st }}$ Parity } & \multicolumn{2}{|c|}{$2^{\text {nd }}$ Parity } & \multicolumn{2}{|c|}{$3^{\text {rd }}$ Parity } & \multicolumn{2}{|c|}{$4^{\text {th }}$ Parity } & \multicolumn{2}{|c|}{$5^{\text {th }}$ Parity } \\
\hline $\mathbf{A}$ & \multicolumn{2}{|c|}{0.020691} & \multicolumn{2}{|c|}{0.091537} & \multicolumn{2}{|c|}{0.291534} & \multicolumn{2}{|c|}{1.987654} & \multicolumn{2}{|c|}{1.998354} \\
\hline $\boldsymbol{X}$ & \multicolumn{2}{|c|}{3.015341} & \multicolumn{2}{|c|}{4.015347} & \multicolumn{2}{|c|}{4.112541} & \multicolumn{2}{|c|}{3.809603} & \multicolumn{2}{|c|}{4.783147} \\
\hline$X^{2}$ & \multicolumn{2}{|c|}{-0.918378} & \multicolumn{2}{|c|}{-0.932571} & \multicolumn{2}{|c|}{-0.614782} & \multicolumn{2}{|c|}{-0.500731} & \multicolumn{2}{|c|}{-1.008939} \\
\hline$X^{3}$ & \multicolumn{2}{|c|}{0.005743} & \multicolumn{2}{|c|}{0.021376} & \multicolumn{2}{|c|}{0.009937} & \multicolumn{2}{|c|}{0.009974} & \multicolumn{2}{|c|}{0.085967} \\
\hline \multirow[t]{3}{*}{$X^{4}$} & \multicolumn{2}{|c|}{1.971538} & \multicolumn{2}{|c|}{3.112570} & \multicolumn{2}{|c|}{3.113478} & \multicolumn{2}{|c|}{4.844677} & 6.283 & \\
\hline & $\mathrm{I}^{\text {st } \mathrm{Pa}}$ & & $2^{\text {nd }} \mathrm{I}$ & & $3^{r d} P$ & & $4^{\text {th } P}$ & & $5^{\text {th }} P$ & \\
\hline & Pre $^{1}$ & $\mathbf{A c t}^{2}$ & Pre & Act & Pre & Act & Pre & Act & Pre & Act \\
\hline Mean & 3.65 & 3.80 & 4.21 & 4.54 & 5.54 & 6.07 & 6.01 & 6.45 & 6.56 & 7.02 \\
\hline$S D$ & 0.11 & 1.03 & 0.91 & 1.43 & 1.22 & 1.03 & 0.97 & 1.16 & 1.11 & 1.81 \\
\hline $\operatorname{Min}$ & 3.45 & 2.00 & 3.91 & 2.19 & 4.61 & 3.38 & 5.43 & 3.50 & 4.21 & 3.97 \\
\hline $\operatorname{Max}$ & 3.97 & 5.50 & 4.95 & 7.10 & 6.18 & 7.80 & 7.18 & 8.71 & 8.02 & 10.5 \\
\hline $\boldsymbol{R}_{a p}$ & 0.94 & & 0.88 & & 0.84 & & 0.79 & & 0.81 & \\
\hline$S E$ & 0.13 & & 0.19 & & 0.23 & & 0.18 & & 0.22 & \\
\hline MIM & & arity & & arity & & arity & & arity & & arity \\
\hline$A$ & 0.008 & & 0.057 & & 0.35 & & 2.058 & & 1.53 & \\
\hline$X$ & 2.416 & & 3.106 & & 3.488 & & 3.292 & & 4.29 & \\
\hline$X^{2}$ & -0.33 & & -0.44 & & -0.54 & & -0.52 & & -0.66 & \\
\hline$X^{3}$ & 0.012 & & 0.017 & & 0.024 & & 0.023 & & 0.02 & \\
\hline$X^{4}$ & 2.098 & & 2.732 & & 3.328 & & 4.844 & & 5.18 & \\
\hline & $\mathrm{I}^{s t} \mathrm{~Pa}$ & & $2^{\text {nd }} \mathrm{I}$ & & $3^{r d} P$ & & $4^{\text {th }} P$ & & $5^{t h} P$ & \\
\hline & Pre & Act & Pre & Act & Pre & Act & Pre & Act & Pre & Act \\
\hline Mean & 3.61 & 3.92 & 3.73 & 4.54 & 5.59 & 6.07 & 6.11 & 6.18 & 5.18 & 6.72 \\
\hline$S D$ & 0.08 & 1.13 & 0.90 & 1.17 & 1.02 & 0.83 & 1.03 & 1.12 & 0.97 & 0.91 \\
\hline Min & 3.42 & 2.80 & 4.01 & 3.07 & 4.78 & 4.98 & 5.11 & 4.08 & 5.28 & 4.97 \\
\hline $\operatorname{Max}$ & 3.62 & 4.32 & 4.93 & 6.11 & 7.03 & 8.11 & 7.10 & 8.11 & 8.28 & 9.68 \\
\hline $\boldsymbol{R}_{a p}$ & 0.91 & & 0.82 & & 0.87 & & 0.92 & & 0.75 & \\
\hline$S E$ & 0.17 & & 0.23 & & 0.25 & & 0.22 & & 0.24 & \\
\hline
\end{tabular}

1: predicted; 2: actual

Table 5-c

Prediction equations for daily milk yield across days (DIM) and months (MIM) of lactation for age at first calving groups

\begin{tabular}{|c|c|c|c|c|c|c|c|c|}
\hline DIM & \multicolumn{2}{|c|}{ All } & \multicolumn{2}{|c|}{$\leq 32$ mon } & \multicolumn{2}{|c|}{$32-40$ mon } & \multicolumn{2}{|c|}{$\geq 40 \mathrm{mon}$} \\
\hline $\mathbf{A}$ & \multicolumn{2}{|c|}{0.020691} & \multicolumn{2}{|c|}{0.0815253} & \multicolumn{2}{|c|}{1.82143661} & \multicolumn{2}{|c|}{0.9326264} \\
\hline$X$ & \multicolumn{2}{|c|}{3.015341} & \multicolumn{2}{|c|}{2.1152476} & \multicolumn{2}{|c|}{2.18242436} & \multicolumn{2}{|c|}{4.11526344} \\
\hline$X^{2}$ & \multicolumn{2}{|c|}{-0.918378} & \multicolumn{2}{|c|}{-0.9901476} & \multicolumn{2}{|c|}{-0.99133681} & \multicolumn{2}{|c|}{-0.15243987} \\
\hline$X^{3}$ & \multicolumn{2}{|c|}{0.005743} & \multicolumn{2}{|c|}{3.2543693} & \multicolumn{2}{|c|}{0.08123698} & \multicolumn{2}{|c|}{0.77412365} \\
\hline$X^{4}$ & \multicolumn{2}{|c|}{1.971538} & \multicolumn{2}{|c|}{2.18324758} & \multicolumn{2}{|c|}{2.00874521} & \multicolumn{2}{|c|}{2.10042415} \\
\hline & \multicolumn{2}{|c|}{ All } & \multicolumn{2}{|c|}{$<32$ mon } & \multicolumn{2}{|c|}{$32-40$ mon } & \multicolumn{2}{|c|}{$>40$ mon } \\
\hline & Pre & Act & Pre & Act & Pre & Act & Pre & Act \\
\hline Mean & 3.61 & 3.92 & 2.85 & 3.01 & 3.73 & 3.65 & 4.25 & 4.18 \\
\hline$S D$ & 0.08 & 1.13 & 0.11 & 0.10 & 0.98 & 1.10 & 0.54 & 0.93 \\
\hline Min & 3.42 & 2.80 & 2.19 & 2.54 & 3.17 & 3.01 & 3.71 & 3.48 \\
\hline $\operatorname{Max}$ & 3.62 & 4.32 & 3.25 & 3.77 & 3.59 & 4.82 & 4.25 & 5.76 \\
\hline$R_{n n}$ & 0.94 & & 0.93 & & 0.82 & & 0.76 & \\
\hline$S E$ & 0.17 & & $0 . .24$ & & 0.22 & & 0.11 & \\
\hline MUM & \multicolumn{2}{|c|}{ All } & \multicolumn{2}{|c|}{$<32$ mon } & \multicolumn{2}{|c|}{$32-40 \mathrm{mon}$} & & mon \\
\hline A & & 615 & & 2436 & & 5241 & & 2471 \\
\hline$X$ & & 172 & & 0214 & & 2411 & & 36942 \\
\hline$X^{2}$ & & 580 & & 5774 & & 01225 & & 22361 \\
\hline$X^{3}$ & & 992 & & 8325 & & 3141 & & 2332 \\
\hline$X^{4}$ & & 203 & & 3369 & & 3143 & & 36523 \\
\hline & & & & non & & mon & & mon \\
\hline & Pre & Act & Pre & Act & Pre & Act & Pre & Act \\
\hline Mean & 3.97 & 3.90 & 3.01 & 3.07 & 3.96 & 4.17 & 4.11 & 4.53 \\
\hline$S D$ & 1.11 & 0.87 & 0.93 & 0.58 & 0.96 & 1.07 & 1.03 & 1.11 \\
\hline Min & 2.32 & 2.27 & 1.78 & 1.90 & 2.01 & 1.99 & 2.59 & 2.55 \\
\hline $\operatorname{Max}$ & 6.01 & 5.55 & 4.01 & 3.98 & 5.83 & 5.91 & 6.89 & 6.75 \\
\hline$R_{a n}$ & 0.91 & & 0.97 & & 0.84 & & 0.86 & \\
\hline$S E$ & 0.17 & & 0.24 & & 0.22 & & 0.11 & \\
\hline
\end{tabular}

The highest intercept value for DIM-TDY obtained at age at first calving group of $>32-\leq 40$ months. On the other hand, all intercept values of MIM-TDY were lower than the corresponding estimates of DIM-TDY. The $4^{\text {th }}$ degree of the polynomial 
function of DIM were similar for all age at calving groups, while the corresponding estimates of MIM-TDY decreased with advancing age at first calving.

The accuracy estimates of predicted TDY values were very high for analyzing the data set of the first age group than the other age groups. Partial regression coefficient of the $2^{\text {nd }}$ degree of the polynomial function for age at first calving group of $\leq 32$ and $>32$ $\leq 40$ for DIM were approximate similar in magnitude to that of MIM. While the rate of increasing TDY predicted values (coefficient of $X$ ) becomes low with advancing order of days in milk for $>40$ months of age at first calving compared to the other age groups.

The highest increasing rate of the predicted both DIM and MIM-TDY values was obtained at the linear component of the polynomial function (coefficient of $X$ ) for age at first calving group of $>40$ months. In addition, the highest reduction rate in the $2^{\text {nd }}$ polynomial degree was attained for the age groups of $\leq 32$ and $>32-\leq 40$ months.

\section{Conclusion}

Two data sets of Egyptian buffaloes were considered for analysis of variance according to lactation length. The first data set is TDY of the short lactation and the $2^{\text {nd }}$ for long lactation. Daily milk yield prediction equations (polynomial regression functions) were investigated using multiple lactations, separate lactations, and three groups of age at first calving.

Influence of stage of lactation on variation of TDY was significant for $\mathrm{LP}_{\mathrm{L}}$ of the pooled data set and $1^{\text {st }}$ parity. Influence of stage of lactation on variation in TDY its progressive nature with increasing length of lactation period. Increasing TDY from the $1^{\text {st }}$ to the $2^{\text {nd }}$ parity was higher than among the other parities. Reduction in TDY from the $4^{\text {th }}$ parity to the $5^{\text {th }}$ parity was higher for $\mathrm{LP}_{\mathrm{L}}$ than for $\mathrm{LP}_{\mathrm{S}}$.

The highest contribution for herd effect was computed with analysis the data set of $\mathrm{LP}_{\mathrm{S}}$ of the $1^{\text {st }}$ parity.

Polynomial function of the $4^{\text {th }}$ degree was created for estimating predicted TDY across months and days of lactation (multiple lactations, separate parities and age at $1^{\text {st }}$ calving groups). Across 390 days of lactation, it could estimate the predicted TDY values by substituting $X=1$ to 390 days in milk in DIM equation. Across 13 months of lactation, it could estimate predicted TDY/month by substituting $\mathrm{X}=1$ to 13 months in milk in MIM equation.

Accuracy estimates of predicted TDY values across months and days of lactation were very high and significant. Therefore, applying these equations in the practical fields could help the farmer for planing his culling strategy of unsuitable dairy animals.

\section{References}

ASHMAWY, A.A.:

Repeatability of productive traits in Egyptian buffaloes. J. Anim. Breed. Genet. 108 (1991), 182-189

BOLDMAN, K.G.;. KRIESE, L.A.; VAN VLECK, L.D.; VAN TASSELL, C.P.; KACHMAN, S.D.:

A Manual for Use of MTDFREML. A set of programs to obtain estimates of variances and covariances. U.S. Department of Agric., Agric. Res. Service. 1997

ABUBAKR, H.A; MANSOUR, H.;.GALAL, E.S.E; SULTAN, Z.:

A genetic study on the lactation curve in Friesian cattle. Egyptian J. Animal Prod. 35, Suppl. Issue, Dec. (1998), 665-680

KAWTHAR, A.M.; KHATTAB, A.S.: 
Adjusting milk yield for age at calving within parity in Egyptian Buffaloes Egyptian J. Anim. Prod. 29 (1992) 2, 185-186

KETTUNEN, A.; MANTYSAARI, E.A.; STRANDEN, I.; POSO, J.; LIDAUER, M.:

Estimation of genetic parameters for first lactation Test-day milk production using random regression models. Proc. $6^{\text {th }}$ World Congr. Genet. Appl. Livest. Prod. Armidale, Vol. 23 (1998), 307-310

KHALIL, M.H.:

Days-open adjustment factors and genetic evaluation for lactation traits in Egyptian buffaloes. Ann. Agri. Sci., Moshtohor 31 (1993), 865-884

KHATTAB, A.S.; MOURAD, K.A.; ASHMAWY, A.A.; EL-HALAWANY, R.:

Milk production of the first lactation as affected by age at first calving in Egyptian buffaloes. J. of Agr. Res. Tanta Uni. Egypt. 11 (1985) 3, 619-627

KOTBY. E.A.; EL-SOBHY, H.F.; MOURAD, K.A.; EID I.N.:

Milk yield in two herds of Egyptian buffaloes in different lactations. Proc. Inter. Symp. Constraints and possibilities of ruminant production in the dry subtropic. Egypt 5-7 Nov. 38 (1988), 145-147

MADALENA, F.E.; MARTIZ, M.L.; FREITAS, A.F.:

Lactation curves of Holstein-Friesian and Holstein-Friesian x gir cows. Anim. Prod. 29 (1979), 101

METRY, G.H.; MOURAD, K.A.; WILK, J.C.; MCDANEL, B.T.:

Lactation curves for first lactation Egyptian Buffalo. J. Dairy Sci. 77 (1994), 1306-1314

MOURAD, K.A.:

Genetic improvement in a herd of Egyptian buffaloes. Ph.D. Thesis, Zagazig University, Banha Branch, Moshtohor. Egypt. 1984

MOURAD, K.A.; AFIFI, E.A.; BEDEIR, L.H.:

Non-genetic factors influuencing milk production traits in Egyptian buffaloes. Egypt. J. Anim. Prod. 27 (1990), 1

RAGAB, M. T.; ABDEL-AZIZ, A.S.; KAMAL, A.:

Effect of farm, parity and season of calving on the lactation curve in buffaloes. Egypt. J. Anim. Prod. 13 (1973), 123

RASHAD, L.H.:

A study on buffalo productivity. M.Sc. Thesis, Faculty of Agri. Cairo Uni. Egypt. 1989

REDDY, C.E.; TANEJA, V.K.:

A note of factors influences the first lactation traits of Nili-Ravi buffaloes. Indian J. Dairy Sci. 37 (1984), 36

REENTS, R.; DOPP, L.:

Genetic variation for dairy production traits with a Test-day model for multiple lactations. INTERBULL Open mtg., Veldhoven. 23-24 June. Bull 14 ${ }^{\text {th }}$ Int. Bull Eval. Serv., Uppsala, pp. 113-117. 1996

SALEM, A.Y.:

Effect of non-genetic factors on milk yield of buffaloes in Egypt. M.Sc. Thesis, Fac, Agric. Tanta Univ., Kafr El-Sheikh, Egypt. 1983

SAS Institute, Inc. SAS/STAT ${ }^{\mathrm{TM}}$ V 6.12 Guide for personal Computers. SAS Inst., Cary , NC. 1989

SCHAEFFER, L.R.; DEKKERS, J.C.M.:

Random regressions in animal models for test-day production in dairy cattle. Proc. $5^{\text {th }}$ World Congr. Genet. Appl. Livest. Prod. Guelp, Vol. 18 (1994), 443-446

SINGH, C.V.; YADAV, M.C.:

Non-genetic factors affecting daily milk yield in Murrah buffaloes. Indian J. of Animal Sci. 57 (1987) 1, 56-58

VEERKAMP, R.F.; THOMPSON, R..

A covariance function for feed intake, live weight, and milk yield estimated using a random regression model. J. Dairy Sci. 82 (1999), 1565-1573

Received: 2002-06-27

Accepted: 2002-12-20

Authors address

Dr. ASHRAF A. AMIN

Department of Animal Production, Faculty of Agriculture,

Suez Canal University

41522-Ismailia / Egypt

E-Mail: aashraf20@hotmail.com 